\title{
Osteochondral Injury, Management and Tissue Engineering Approaches
}

\author{
George Jacob ${ }^{1,2}$, Kazunori Shimomura ${ }^{1}$ and Norimasa Nakamura ${ }^{3,4 *}$ \\ ${ }^{1}$ Department of Orthopedic Surgery, Osaka University Graduate School of Medicine, Osaka, Japan, ${ }^{2}$ Department \\ of Orthopedics, Tejasvini Hospital, Mangalore, India, ${ }^{3}$ Institute for Medical Science in Sports, Osaka Health Science \\ University, Osaka, Japan, ${ }^{4}$ Global Center for Medical Engineering and Informatics, Osaka University, Osaka, Japan
}

\section{OPEN ACCESS}

Edited by:

Takashi Nakamura,

Tohoku University, Japan

Reviewed by:

Susanne Grässel,

University of Regensburg, Germany

Ke Xue,

Shanghai Jiao Tong University, China

Salvatore Rinaldi,

Istituto Rinaldi Fontani, Italy

*Correspondence:

Norimasa Nakamura

norimasa.nakamura@ohsu.ac.jp

Specialty section:

This article was submitted to

Stem Cell Research,

a section of the journal

Frontiers in Cell and Developmental

Biology

Received: 07 July 2020

Accepted: 22 September 2020

Published: 04 November 2020

Citation:

Jacob G, Shimomura K and Nakamura N (2020) Osteochondral Injury, Management and Tissue

Engineering Approaches.

Front. Cell Dev. Biol. 8:580868. doi: 10.3389/fcell.2020.580868
Osteochondral lesions (OL) are a common clinical problem for orthopedic surgeons worldwide and are associated with multiple clinical scenarios ranging from trauma to osteonecrosis. OL vary from chondral lesions in that they involve the subchondral bone and chondral surface, making their management more complex than an isolated chondral injury. Subchondral bone involvement allows for a natural healing response from the body as marrow elements are able to come into contact with the defect site. However, this repair is inadequate resulting in fibrous scar tissue. The second differentiating feature of $\mathrm{OL}$ is that damage to the subchondral bone has deleterious effects on the mechanical strength and nutritive capabilities to the chondral joint surface. The clinical solution must, therefore, address both the articular cartilage as well as the subchondral bone beneath it to restore and preserve joint health. Both cartilage and subchondral bone have distinctive functional requirements and therefore their physical and biological characteristics are very much dissimilar, yet they must work together as one unit for ideal joint functioning. In the past, the obvious solution was autologous graft transfer, where an osteochondral bone plug was harvested from a non-weight bearing portion of the joint and implanted into the defect site. Allografts have been utilized similarly to eliminate the donor site morbidity associated with autologous techniques and overall results have been good but both techniques have their drawbacks and limitations. Tissue engineering has thus been an attractive option to create multiphasic scaffolds and implants. Biphasic and triphasic implants have been under explored and have both a chondral and subchondral component with an interface between the two to deliver an implant which is biocompatible and emulates the osteochondral unit as a whole. It has been a challenge to develop such implants and many manufacturing techniques have been utilized to bring together two unalike materials and combine them with cellular therapies. We summarize the functions of the osteochondral unit and describe the currently available management techniques under study.

Keywords: osteochondral repair, Tissue Engineering and Regenerative Medicine, articular cartilage, multiphasic scaffold, Mesenchymal stem cell

\section{INTRODUCTION}

Osteochondral lesions (OL) are a morphological finding as a result of an acute trauma or occur due to osteochondritis dissecans, osteoarthritis (OA), subchondral insufficiency fractures or osteonecrosis (Gorbachova et al., 2018). OLs pose a difficult clinical situation for joint preservation surgeons as they extend beyond the articular cartilage into the subchondral bone and marrow 
(Gorbachova et al., 2018). The additional injury to the underlying structural support system along with the articular cartilage demands a more comprehensive clinical solution.

Due to the avascular nature of cartilage tissue, it is beyond the reach of reparative growth factors and cells, therefore not fortunate to follow normal tissue injury response (Temenoff and Mikos, 2000; Sophia Fox et al., 2009). The natural healing of OLs vary from that of chondral lesions due to their subchondral extension resulting in spontaneous cellular repair (Charalambous, 2014). This natural response leads to the formation of unsatisfactory fibrocartilage and the articular surface degenerates over time (Ochi et al., 2001) progressing toward OA. OL treatment strategies must aim to address both the subchondral bone and chondral surface above it (Gomoll et al., 2010). Current techniques include autologous chondrocyte implantation (ACI), osteochondral grafting and a combination of $\mathrm{ACI}$ and grafting, depending on the lesion. More recent treatments have employed tissue engineering and stem cell therapies using biphasic and triphasic scaffolds to provide effective osteochondral repair. We aim to focus on the osteochondral unit, its management and new emerging technologies for OL treatment.

\section{ANATOMY OF CARTILAGE AND SUBCHONDRAL BONE}

The osteochondral unit consists of a articular chondral component and a deeper subchondral bone component (Madry et al., 2010). Cartilage is composed mainly of a dense extracellular matrix (ECM) made up of water, type II collagen, and proteoglycans (Buckwalter and Mankin, 1997; Keeney and Pandit, 2009). Within the cartilage tissue lies specialized cells known as chondrocytes (Sophia Fox et al., 2009). Cartilage is distinct in that it is completely devoid of blood vessels, lymphatics, and nerves (Buckwalter and Mankin, 1997; Sofat et al., 2011). It is divided into four zones, the superficial, the middle, the deep, and the calcified cartilage zone. Each zone having a unique cell orientation, collagen fiber arrangement and ECM composition allowing it to fulfill different biomechanical functions. For example, the superficial zone serves to protect the deeper zones from shear forces while the deeper zones are better arranged to counter compressive forces (Sophia Fox et al., 2009).

The deepest tissue of the osteochondral unit is the subchondral bone. Bone consists mainly of hydroxyapatite (HA) and type I collagen which contribute to the strength and stiffness of bone tissue (Yang and Temenoff, 2009; Arvidson et al., 2011). The subchondral bone region consists of thick plates joined together to form a subchondral bone plate below which is the subarticular spongiosa (Lopa and Madry, 2014). Separating the cartilage tissue and the bone is a complex junction known as the osteochondral junction also referred to by some authors as the chondro-osseous junction. It consists of the deepest zone of uncalcified cartilage, the tidemark, a layer of calcified cartilage, a thin line known as the cement line and beyond this the subchondral bone (Lyons et al., 2006). It is the tidemark that separates the non-calcified and calcified layer of cartilage from each other as a histologic wavy boundary up to $10 \mu \mathrm{m}$ in thickness (Gannon and Sokoloff, 1999). Calcified cartilage has a lower mechanical strength than the bone below it (Mente and Lewis, 1994), however, a few unique features aid in better integration between the two layers (Nooeaid et al., 2012). Such as prolonged extensions of uncalcified cartilage extending through the calcified layer to abut the subchondral bone but not beyond it (Hunter et al., 2009). Also, the wavy nature of the tidemark and its vertically oriented fibers (Oegema et al., 1997). The junction is not impermeable (Madry et al., 2010) and a large number of arteries, veins, and nerves (Pan et al., 2009) send branches through minute canals within the subchondral plate into the calcified cartilage. This is the route by which nutrients are brought to the articular cartilage and a homeostatic environment maintained. In the setting of $\mathrm{OA}$, there is the loss of articular cartilage, subchondral thickening, and formation of osteophytes (Haverkamp et al., 2011; Loeser et al., 2012) leading to loss of the normal biochemical and biomechanical processes Figure 1. Illustrates the cross-sectional anatomy of the osteochondral unit.

\section{BIOMECHANICS OF THE OSTEOCHONDRAL UNIT}

The osteochondral unit performs several functions with each layer of the tissue having a specific and some overlapping roles. The chondral and subchondral tissues are separated by a chondro-osseous junction allowing them to work together to help the entire osteochondral unit accomplish its responsibilities in maintaining healthy joint homeostasis (Lyons et al., 2006).

The chondral layer being the most superficial layer of the osteochondral unit is subjected to a greater number of force vectors. As with most of the osteochondral unit, the chondral layer must withstand compressive forces but in addition to this, it must also counter friction and shear forces generated cyclically during normal joint articulation. Chondral tissue is best described as being biphasic as it demonstrated features of both a fluid and solid phase substance. Water and inorganic ions such as sodium, potassium, calcium and chloride are responsible for its fluid phase and ECM for its solid phase (Sophia Fox et al., 2009). With the presence of negatively charged proteoglycans (Ghadially, 1981) and the porous permeable ECM (Mow et al., 1984; Ateshian et al., 1997), interstitial fluids can move in and out of the tissue with the increasing and decreasing joint forces (Maroudas and Bullough, 1968; Mow et al., 1984; Frank and Grodzinsky, 1987). This summarizes the flow-dependent mechanism which allows for the chondral tissue to exhibit a biphasic viscoelastic behavior (Mow et al., 1980). The flow independent mechanism is brought about by the viscoelastic behavior of the collagenproteoglycan matrix (Hayes and Bodine, 1978; Woo et al., 1987). As the forces increase on the chondral tissue the tissue becomes stiffer and more resistant to the forces applied due to these mechanisms. 


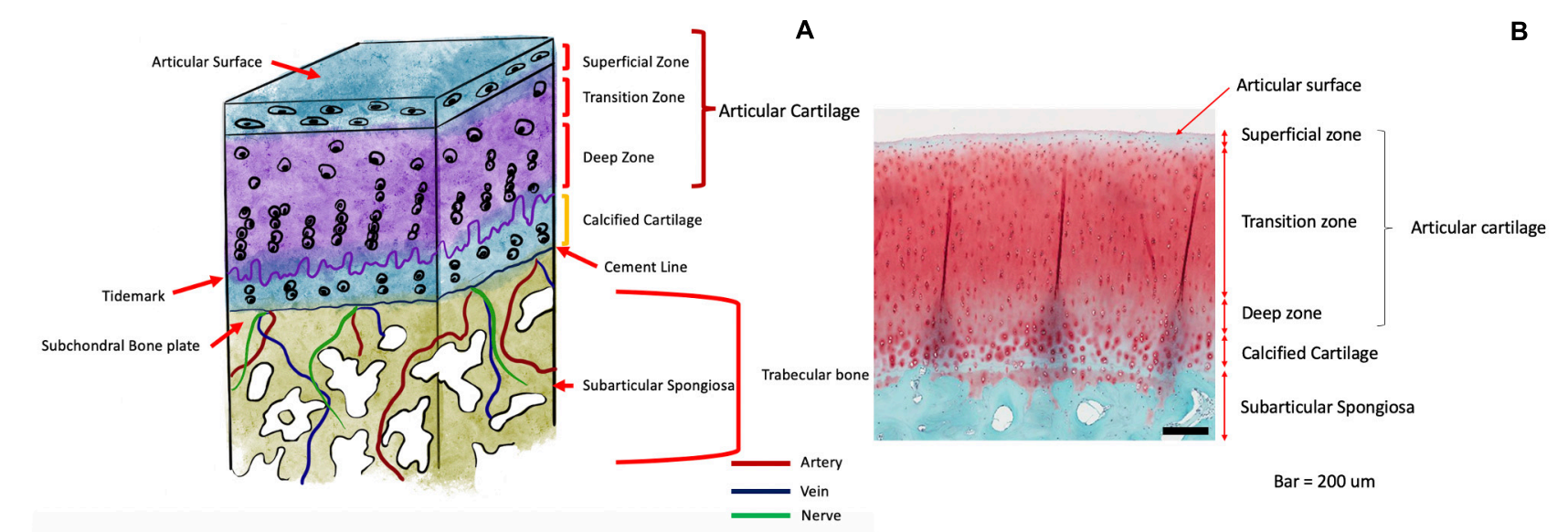

FIGURE 1 | (A) Schematic Illustration of the anatomy of the osteochondral unit. (B) Histologic image of the osteochondral unit.

The osteochondral junction is an integral region in the osteochondral unit allowing for communication between the lower subchondral bone and the upper chondral surface. This region encompasses arteries, nerves, and veins that extend from the subchondral bone up to the calcified cartilage, where nutrient exchange is facilitated (Honner and Thompson, 1971). It is also responsible for mineralization, directing cells into various types of chondrocytes. The calcified cartilage layer interdigitates with the subchondral bone and contains chondrocytes embedded within a mineralized ECM. These features help in giving it a high stiffness to anchor the cartilage to the subchondral bone below (Mente and Lewis, 1994).

The subchondral bone consists of impermeable compact bone with many penetrating vascular canals allowing it to play a role in both strength and nutrition to the tissues above it (Duncan et al., 1987; Aigner and Dudhia, 1997; Imhof et al., 2000). Sensory neurons innervate the subchondral bone region and provide nociception (Lepage et al., 2019). The deeper layers of the subchondral bone consist of trabecular bone which can absorb and dissipate the forces applied across the joint (Stewart and Kawcak, 2018) Figure 2. Summarizes the various specific roles of each layer of the osteochondral unit.

\section{DIAGNOSIS OF AN OSTEOCHONDRAL LESION}

Clinical diagnosis of an OL can be elusive, when relying purely on patient complaints and clinical examination. Common complaints may or may not include an episode of trauma, however, there usually will be complaints of pain, swelling, crepitus, and possible history of knee locking. An examination may reveal joint line tenderness depending on the OL location and with associated injuries special meniscal and ligament tests may be positive. Older clinical tests for OLs such as Wilson's test seem to not be of diagnostic value (Conrad and Stanitski, 2003).

Radiological diagnosis of an OL can be done by X-ray and computed tomography, but magnetic resonance imaging (MRI)

\begin{tabular}{|c|c|c|}
\hline Chondral layer & $\begin{array}{l}\text { Chondro-osseous } \\
\text { junction }\end{array}$ & $\begin{array}{l}\text { Subchondral } \\
\text { bone }\end{array}$ \\
\hline $\begin{array}{l}\text { - Load dispertion } \\
\text { - Mechanical } \\
\text { strength } \\
\text { - Frictionless } \\
\text { motion } \\
\text { - Elasticity } \\
\text { - Surface } \\
\text { integrity }\end{array}$ & $\begin{array}{l}\text { - Joint Nutrition } \\
\text { - Mineralization } \\
\text { - Force transfer } \\
\text { from cartilage } \\
\text { to bone } \\
\text { - Anchorage of } \\
\text { cartilage to } \\
\text { bone }\end{array}$ & $\begin{array}{l}\text { - Mechanical } \\
\text { strength } \\
\text { - Nutrition } \\
\text { - Nociception }\end{array}$ \\
\hline
\end{tabular}

has shown to be more useful especially in earlier stages of OL development. It can also detect earlier subchondral bone changes predisposing to OLs (Gorbachova et al., 2018). Thus, MRI with cartilage mapping software and sequences are the gold standard for radiologic evaluation of joint surfaces (Lepage et al., 2019). MRI has an important advantage over arthroscopy in that the status of the subchondral can be studied. MRI is also noninvasive and functions without the need of ionizing radiation and therefore well suited for OL evaluation. MRI studies allow for determination of lesion size, location, presence of bone marrow lesions, fracture lines, and subchondral plate deformities. These features can be used to make a diagnosis of the primary causes of the OL. Newer less invasive diagnostic arthroscopic techniques are being introduced and may be a useful tool in the outpatient clinic such as needle arthroscopy (McMillan et al., 2017) but can still only visualize the superficial chondral surface. It is also important to note that the clinical symptoms of an OL and diagnostic imaging may not correlate (Guermazi et al., 2012) making treatment decisions less straightforward. Additionally, it is important to diagnose the cause and chronicity of an OL. Acute traumatic lesions are a simpler clinical scenario while 
older more chronic lesions result in global degeneration of the involved joint. This eventually results in negative biochemical and biomechanical changes in the joint where most repair and regenerative treatments are no longer options and patients may have to consider other treatments such as arthroplasty.

\section{REPAIR TECHNIQUES}

\section{Osteochondral Fragment Fixation}

In certain acute traumatic OLs, there may be a large osteochondral fragment present within the joint that can be reduced and fixed back into the defect site. This is usually limited by the time from injury and the integrity and size of the fragment. Numerous fixation techniques have been described such as screws (Thomson, 1987; Herring et al., 2019), metal/bioabsorbable pins (Hirsch and Boman, 1998; Gkiokas et al., 2012), fibrin glue (Jeuken et al., 2019), and sutures (Vogel et al., 2020). Satisfactory osteochondral fragment union rates have been reported for each technique but there are some disadvantages and complications associated with each method (Gkiokas et al., 2012; Barrett et al., 2016; Herring et al., 2019) such as the requirement for second stage implant removal, tissue reactions, delayed degradation, and subchondral remodeling (Pascual-Garrido et al., 2009; Millington et al., 2010). Newer suture techniques have been described aiming to reduce the tissue reaction, implant footprint and requirement for implant removal (Vogel et al., 2020). Fixation in the case of a large acute osteochondral fragment should always be considered as the first option of treatment for an OL.

\section{Osteochondral Autologous Graft Transfer}

Osteochondral autograft transfer (OAT) has been a popular technique since its first introduction by Matsusue et al. (1993). Here healthy articular cartilage and it's underlying subchondral bone is harvested as a cylindrical plug, usually from the nonweight bearing region of the femoral trochlea. This cylinder is contoured to match the lesion site allowing for repair with smooth, healthy, mature, hyaline cartilage. The procedure can also be performed using a combination of multiple smaller diameter cylinders known as mosaicplasty. The advantages and disadvantages of OAT are summarized in Table 1. OAT has proven to be an attractive option in knee joint preservation surgery demonstrating good clinical outcomes and long term results, especially in lesions smaller than $2 \mathrm{~cm}^{2}$ (Gudas et al., 2012; Ulstein et al., 2014; Lynch et al., 2015; Pareek et al., 2016; Richter et al., 2016; Solheim et al., 2018). There is no difference in outcomes based on lesion location when assessing lesions on the femur, however, Bentley et al did report inferior outcomes when treating patellar lesions (Bentley et al., 2003). The main limitation for larger lesions is the amount of tissue required from the donor site and greater amounts of donor tissue lead to possibly increased donor site morbidity. It is in situations where larger amounts of donor tissue where a surgeon may have to resort to allogeneic graft options. A summary of the advantages and disadvantages of OATS can be found in Table $\mathbf{1}$.

\section{Osteochondral Allograft Transplant}

Osteochondral Allograft Transplant (OCA) is a popular technique used especially when dealing with larger OLs where an allograft is used for lesion restoration. This has all the advantages of OATS but with the added advantage of no donor site morbidity. OCA grafts can be fresh, fresh frozen or cryopreserved each having its effect on the chondrogenic viability of the cells within the graft. There is convincing data that patients tolerate allografting to the chondral component of the graft tissue with no immune response (Langer and Gross, 1974). This cannot be said for the subchondral and bony component which does elicit a strong immune response that increases with the size of graft tissue (Kandel et al., 1985; Stevenson et al., 1996). Patient selection is an important consideration in OCA transplantation and results have been superior in younger active patients (Krych et al., 2017; Nielsen et al., 2017). Factors such as age, sex, body mass index, and overall physical fitness play an important role in the prognosis of OCA (Sherman et al., 2014). OCA can be used for lesions $>2 \mathrm{~cm}^{2}$ where marrow stimulation has been shown to have poor results. Over $2 \mathrm{~cm}^{2}$ cell-based techniques and OAT are options but cell-based techniques do not address subchondral bone pathologies and OAT has donor site morbidity. Therefore, OCA is indicated in lesions greater than $2 \mathrm{~cm}^{2}$ where autologous donor tissue is unavailable or insufficient. The indications of OCA have even extended to include the femoral hemicondyle, entire condyle, and even tibial plateau depending on the patient's requirement (McCulloch et al., 2007; Williams et al., 2007; Levy et al., 2013). A summary of the advantages and disadvantages of OCA can be found in Table 2.

\section{REGENERATIVE TECHNIQUES}

Osteochondral unit regeneration is challenging owing to its complex anatomy and demanding functions. Both the chondral and subchondral layers must be regenerated for the regenerate to resemble native cartilage (Schek et al., 2004; Kon et al., 2011;

TABLE 1 | Summary of the advantages and disadvantages of OATS.

\begin{tabular}{ll}
\hline Advantages & Disadvantages \\
\hline Mature hyaline cartilage & Limited quantity \\
No chance of immune response & Donor site morbidity \\
Immediate fill of lesion & Possibly $>1$ surgical site \\
No graft availability concerns & Limited lesion size \\
Addresses subchondral and chondral layer &
\end{tabular}

TABLE 2 | Summary of the advantages and disadvantages of OCA.

\section{Advantages}

Mature hyaline cartilage

No limit to size of donor graft

Immediate fill of lesion

Addresses subchondral and

chondral layer

No donor site morbidity

\section{Disadvantages}

Immunogenicity concerns

Banked tissue therefore less cell viability Difficult to procure and store Additional expense

Possible graft size mismatching 
Orth et al., 2013). In addition, both layers should integrate with the surrounding cartilage and bone tissue. Attempts have been made by developing biphasic scaffolds that have an osseous layer providing rigid, structural support incorporated to a more bioactive chondral layer into which cells may be seeded. It has been postulated that a triphasic scaffold with an intermediate layer between the chondral and bone layers would be beneficial and emulate the tidemark found in a native osteochondral unit (Marquass et al., 2010; Longley et al., 2018). This intermediate layer would have to mimic the osteochondral junction containing intricate networks of arteries and nerves with no currently available faultless biomaterial. Finally, the subchondral region would have to promote bony ingrowth from the surrounding tissue and have a low elastic modulus, providing strength to the entire construct. Figure 3 outlines the ideal requirements of a regenerated osteochondral unit.

\section{Cells}

As mentioned earlier a regenerative osteochondral implant must be bioactive and the most important factor to achieve this is the addition of a cells. Various cell sources have been studied and employed such as embryonic stem cells (ESCs) and MSCs. MSCs have remained more popular given the ethical obstacles associated with ESCs (Lo and Parham, 2009). MSCs have been derived from a variety of tissues such as bone marrow (Mafi, 2011), adipose (Berebichez-Fridman et al., 2017), synovium (Sakaguchi et al., 2005), periosteum (de Mara et al., 2011), muscle (Jackson et al., 2010), dental pulp (Pierdomenico et al., 2005), and many more. More recently the discovery of the induced pluripotent stem cell (iPS cell) has made available a more easily accessible cell source with superior differentiation and proliferative potential (Takahashi and Yamanaka, 2006; Yu et al., 2007). Embryonic and induced pluripotent stem cells can differentiate into any of the three germ layers therefore along with having limitless proliferative potential and superior differentiation capacity they both pose a risk of teratoma formation (Tsumaki et al., 2015; Chijimatsu et al., 2017). Each MSC source has its own advantages and disadvantages. Concerning cell number harvest, adipose has shown the greatest yield while bone

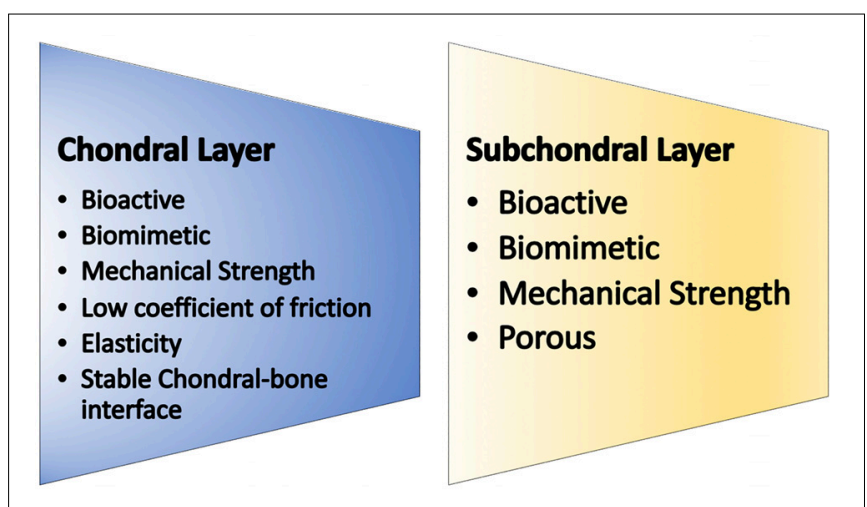

FIGURE 3 | The ideal osteochondral unit. marrow the least (Baer and Geiger, 2012; Chahla et al., 2016). Synovium has demonstrated to have the most superior osteogenic and chondrogenic differentiation capacity compared to bone marrow and adipose, however, requires expansion when used in clinical applications (Sakaguchi et al., 2005). The high MSC yield in adipose tissue is beneficial as in vitro expansion has shown to have negative effects on cell homing (Sohni and Verfaillie, 2013).

Cells have been incorporated with tissue engineering for osteochondral regeneration with various techniques investigated till date. In the past, an autologous biopsy of chondrocytes and osteoblasts from the patient done during ACI was the most popular solution as obtaining the cells was easier, however, this did not result in sufficient cell numbers. At the expense of expanding the cells to increase the numbers in primary culture, the cells undergo dedifferentiation and lose their chondrogenic phenotype (Benya and Shaffer, 1982; Stewart et al., 2000; Schnabel et al., 2002; Darling and Athanasiou, 2005). Though ACI has been further improved over the years with the addition of collagen membranes and scaffolds, there is still no evidence that it is superior to other cartilage repair techniques (Samsudin and Kamarul, 2016). ACI also includes the higher cost of two surgeries and donor site morbidity. MSC therapies provide a solution in terms of not requiring a autologous articular cartilage biopsy along with providing pluripotent MSCs which are unlike already differentiated chondrocytes. MSCs can be be differentiated into chondrocytes by first isolating them from any of the aforementioned sources (Sundelacruz and Kaplan, 2009; Mafi, 2011; Nooeaid et al., 2012) or can be cocultured with chondrocytes. This has shown to help maintain chondrocyte phenotype and characteristics (Hubka et al., 2014). It is worth mentioning that iPS cells have been studied for cartilage culture and maybe a promising source of stem cell going forward (Ko et al., 2014; Tsumaki et al., 2015). The most important advantage of using MSCs is that they are bioactive and therefore offer better incorporation with the body and can influence and mediate biological processes effectively. The cells exhibit paracrine functions (Hocking and Gibran, 2010; Barry and Murphy, 2013) which promote cell growth and have anti-inflammatory roles (Johnstone et al., 1998; Freyria and Mallein-Gerin, 2012; Ruiz et al., 2016). MSCs also stimulate endogenous cell recruitment and are involved with immunomodulation as well as secrete exosomes (Kanazawa et al., 2011; Zhang et al., 2020). MSC therapies are, however, considerably expensive and time consuming therefore acellular techniques are being explored (Dhollander et al., 2012; Joshi et al., 2012) though most preclinical data is in favor of cell-seeded scaffolds with a subchondral osteoinductive scaffold (Lopa and Madry, 2014). MSC treatments do, however, remain costly.

\section{Growth Factors}

Growth factors are the most bioactive part of a regenerative process in that they control and initiate a host of cellular mechanisms which lead to superior chondrogenesis and cell proliferation. The most often utilized growth factors for 
chondrogenic differentiation are those in the TGF- $\beta$ superfamily. This consists of bone morphogenic proteins (BMP-2,4,6, 7 ), cartilage-derived morphogenic proteins (CDMP-1,2), and transforming growth factor beta-1 (TGF- $\beta$ ). These factors are especially useful to stimulate chondrogenic differentiation, reverse dedifferentiation and encourage the production of ECM an essential component of chondral tissue. They also have an overall inhibitory effect on catabolic processes mediated by Interleukin-1,6,8 and matrix metalloproteinases (MMP; Salgado et al., 2004; Fortier et al., 2011; Re'Em et al., 2012; Tuan et al., 2013). Fibroblast growth factor (FGF) -2 and 18 play a prominent role in chondrogenic differentiation and seem to have different actions on MSCs and chondrocytes. FGF-2 and FGF-18 promote anabolic and reduce catabolic cell pathways which in turn lead to increased proteoglycan (PG) synthesis in MSCs (Cuevas et al., 1988; Stewart et al., 2007; Fortier et al., 2011). However, pre-clinical data has suggested FGF-2 to have deleterious effects on chondrocyte proliferation especially in higher doses by upregulation of MMP and reducing PG synthesis and increasing inflammation (Tuan et al., 2013). On the other hand FGF-18 has shown to promote chondrocyte proliferation (Ellsworth et al., 2002; Ellman et al., 2008). FGF-2 and TGF- $\beta$ have been noted to work together to enhance cartilage ECM formation under culture conditions of chondrogenic cells and are essential for cartilage homeostasis (Huang et al., 2018). The FGF family does have a prominent effect on MSCs though possibly not as beneficial to chondrocyte metabolism. Another growth factor involved in cartilage synthesis is insulin-like growth factor (IGF-1) which supports the roles of TGF- $\beta$ and BMP-7 and upregulates anabolic mechanisms and downregulates catabolism in the cells. IGF-1 has shown to promote chondrogenic differentiation in MSCs in a synergistic manner alongside TGF$\beta$ and BMP-7 (Loeser et al., 2003; Zhou et al., 2016). It has been noted that with decreased IGF-1 there is reduction in chondrocyte number and proteoglycan synthesis (Wei et al., 2017). Platelet derived growth factor (PGDF) is another growth factor which has a role in increasing chondrocyte proliferation and proteoglycan synthesis. PGDF has also shown to reduce IL- $\beta 1$ levels which are known to cause chondral degradation (Schmidt et al., 2006).

Platelet rich plasma (PRP), autologous conditioned plasma and bone marrow concentrate are considered to be abundant in growth factors and have been used in clinical practice (Jacob et al., 2017). These therapies are manufactured by concentrating blood or bone marrow aspirate using a centrifugation process or specific company system to concentrate native growth factors present in the sample. As there are multiple types of growth factors with varying functional roles being concentrated in these injections both growth factors that promote chondrocyte metabolism and inhibit it are being concentrated (Rutgers et al., 2010). Literature has reported these blood derived products to not be beneficial in promoting chondrogenic differentiation of MSCs (Rutgers et al., 2010; Liou et al., 2018), however, some other studies have shown benefit (Frisbie et al., 2007; Mishra et al., 2009). The advantage of such therapies is the easy availability of autologous growth factors but the major disadvantage is the lack of standardization and determination of exact factor concentrations (Chahla et al., 2017).

\section{Emerging Techniques}

Newer cell culture methods have been explored aiming to alter the cell microenvironment to improve cell differentiation and result in better quality regenerate synthesis (Vats et al., 2006). Three dimensional MSC cultures and scaffolding techniques have shown to be effective in improving cell proliferation (Estes and Guilak, 2011). High density cultures techniques such as micro mass and pellet cultures have demonstrated superior chondrocyte differentiation as the three-dimensional nature of the culture simulates a similar microenvironment to that of tissue during embryogenesis (Pelttari et al., 2008; Zhang et al., 2010). Other explored culture techniques have involved varying hydrostatic pressures, the addition of mechanical loading and use of low oxygen tensions. These variations can be brought about to the cell culture by using bioreactors aiming to replicate physiologic in vivo conditions. Various designs of bioreactors have been manufactured to produced compressive forces, shear forces and even dynamic cyclic loading of the cell culture (Angele et al., 2004; Campbell et al., 2006; Chen et al., 2018). Applying cyclical increasing hydrostatic pressures on MSC cultures has shown to enhance the production of cartilage matrix even in the absence of chondrogenic growth factors (Miyanishi et al., 2006; Puetzer et al., 2013). A large number of studies have reported improved chondrogenesis in cultures exposed to mechanical loading with dynamic, shear or compression forces (Huang et al., 2004; Mouw et al., 2007; Waldman et al., 2007; Villanueva et al., 2009). This emulates joint reaction forces and the additional mechanical stimulation on the chondrocytes results in better chondrogenic differentiation and matrix production. With this evidence it is reasonable to say that for improved chondrogenesis the cells require both growth factors and mechanical forces to bring about more physiological cellular responses.

\section{SCAFFOLDS}

\section{Chondral Layer}

Synthetic polymers or natural biomaterial-based scaffolds are generally utilized for constructing the chondral component of the osteochondral unit. Though, recent reports have utilized scaffold-free implants as well. Because natural-based polymers are fabricated from materials that make up typical natural cellular environments, they may be ideal for cell proliferation with a reduced possibility of unfavorable reactions. Natural polymers may additionally be able to enhance cell proliferation and guide cellular differentiation to more desirable results (Mano and Reis, 2007; Nooeaid et al., 2012). In the process of procuring biocompatibility through these scaffolds they may lack mechanical vigor (Nooeaid et al., 2012). Commonly employed materials include chitosan, collagen, hyaluronic acid, and biobased polymers (Shimomura et al., 2014b). 
Bio-degradable synthetic scaffolds include poly (glycolic acid), poly (L-lactic acid), poly (D, L-lactic-co-glycolic acid), poly (caprolactone), and poly (ethylene glycol). These are superior to natural scaffolds in that their mechanical strength and crystallinity can be varied during manufacture along with the rate at which they undergo degradation (Gunatillake et al., 2003; Kundu et al., 2013). Furthermore, with newer techniques such as electrospinning and 3D printing, scaffold porosity, and shape are easily modifiable and constructed based on the requirement (Woodfield et al., 2005; Li et al., 2007; Thorvaldsson et al., 2008; Duan et al., 2014; Zhou et al., 2018). The major drawback of synthetic scaffolds is their poor bioactivity owing to their hydrophobic surfaces hindering cellular attachment (Bhattarai et al., 2006; Lee et al., 2006). These scaffolds may also be combined with growth factors (Morille et al., 2013; Reyes et al., 2014) and materials such as silica and alkalis to improve their bioactivity (Peña et al., 2006; Buchtová et al., 2013).

Extracellular matrix can provide a form of scaffolding to an osteochondral repair by providing some form of tissue architectural structure as well as bio signaling (Sutherland et al., 2015). Using chemical or physical methods cartilage ECM can be decellularized and then used to facilitate chondrogenic differentiation of MSCs (Cheng et al., 2009; Sutherland et al., 2015). Another method similar to an ECM is the use of a cell-derived matrix such as tissue-engineered construct (TEC) derived from synovial MSCs (Ando et al., 2007). TEC has favorable properties of being superiorly bioactive and highly adherent to the surrounding cartilage matrix. Combining TEC with $\mathrm{HA}$ and beta-tricalcium phosphate has been studied in animal models and shown favorable outcomes of OL repairs with the $\mathrm{HA}$ combination demonstrating better results (Shimomura et al., 2014a, 2017).

Bioceramics encompass both osteoconductive and bioresorbable properties which are favorable in the scenario of an osteochondral repair. To increase the elastic modulus of bioceramics, polymers have been combined with them and have shown encouraging cartilage regenerative results (Xue et al., 2010; Lv and Yu, 2015). Bioactive ions such as lithium, manganese, zinc, and silicon have also been under recent study to improve the bioactivity of the implants and shown promising results (Deng et al., 2017, 2019).

\section{Subchondral Layer}

As mentioned earlier the subchondral bone is responsible for providing compressive strength to the osteochondral unit and has a low elastic modulus. Currently available materials that meet this requirement include metals, bioglass, and bioceramics (Kon et al., 2010; Chen et al., 2011; Zhang et al., 2013; Deng et al., 2017). Metallic compounds are inert and therefore have been popular in orthopedic surgery, however, for integration they must possess a basic level of bioactivity. This led to coating metals with HA and calcium phosphate thereby promoting better implant integration but not addressing the degradation of the material. Magnesium base alloys are now being studied as they possess adequate mechanical strength, bioactivity, and degradation (Yang et al., 2018). Overall, wear particle release and corrosion remain a limitation when using metallic materials (Sonny Bal et al., 2010).
Ceramics and bioglass possess excellent osteoconductive and inductive properties which allow them to bond well to the adjacent host bone (Tamai et al., 2005; Martin et al., 2007). These materials are, however, brittle and can fracture under mechanical loading (Nooeaid et al., 2012; Deng et al., 2019). By modifying the porosity of ceramics, their biodegradability can be effectively altered and titrated to the desired rate. Porosity and mechanical strength are inversely related and the addition of biodegradable polymers can help solve this problem (Miao et al., 2008; Ren et al., 2008). The integration of these subchondral substitution materials with a chondral natural or synthetic polymers, e.g., collagen, hyaluronic acid, poly (glycolic acid) can together manufacture an osteochondral unit with materials that satasify the functions of both the chondral and subchondral layers.

\section{CLINICAL RESULTS OF OSTEOCHONDRAL IMPLANTS}

Clinical data utilizing multiphasic osteochondral implants is sparse along with the fact that only three such osteochondral implants have been used. These are MaioRegen (Fin-Cermica Faenza SpA), TruFit (Smith and Nephew, Andover, MA, United States) and more recently Agili-C (Cartilheal Ltd, Kfar Sava, Israel). MaioRegen and TruFit have been studied and reported further than Agili- C and clinical trial results for Agili$\mathrm{C}$ are awaited.

Recently, D’Ambrosi et al. (2019) published a systematic review on the results of MaioRegen. MaioRegen being a triphasic scaffold aims to closely resemble the osteochondral unit. 471 patients were included in the review with a mean follow up of 24 months. 15 out of the included 16 studies were level IV and only one was a comparative level III study. The included lesions were all ICRS grade III and IV excluding two studies which included spontaneous osteonecrosis of the knee and KellgrenLawrence grade III OA. Clinical outcome scores at 24 months demonstrated significant improvement in thirteen studies with only one study reporting no difference. Histological analysis was reported by only two studies and indicated no residual scaffold with a strong presence of type II collagen and proteoglycan content. This reveals that the implant resorption and regenerative tissue response is adequate. Complications included 2 partial implant detachments, 2 cases of graft hypertrophy, and 52 patients reported minor complications such as joint stiffness and swelling. There were 16 failures in this systematic review. On the whole, the results of MaioRegen have been favorable with good clinical results and a low complication rate, however, the included studies were of a low level of evidence and as a result, they could not conclude that MaioRegen was superior to other treatments till better randomized trials were performed.

TruFit is a biphasic acellular synthetic scaffold mainly composed of a polylactide-coglycolide copolymer for the chondral region and calcium sulfate for the bone region. TruFit has shown to have a clinical benefit at 12 months of follow up but two studies reported worsening on longer follow up as reported by a systematic review in 2015 (Verhaegen et al., 2015). The main complication reported with use of the TruFit implant was 
TABLE 3 | Summarizes the clinical studies using multiphasic scaffolds.

\begin{tabular}{|c|c|c|c|c|c|c|c|}
\hline Author/Year & $\begin{array}{l}\text { Type of } \\
\text { study }\end{array}$ & $\begin{array}{l}\text { Patient } \\
\text { number }\end{array}$ & $\begin{array}{l}\text { Implant specifics/ } \\
\text { company }\end{array}$ & $\begin{array}{l}\text { First clinical } \\
\text { trial }\end{array}$ & $\begin{array}{l}\text { Lesion } \\
\text { size/cm² }\end{array}$ & $\begin{array}{l}\text { Follow } \\
\text { up/months }\end{array}$ & Results \\
\hline D'Ambrosi et al., 2019 & $\begin{array}{l}\text { Systematic } \\
\text { review }\end{array}$ & 471 & $\begin{array}{l}\text { MaioRegen } \\
\text { Triphasic } \\
\text { C: Coll I } \\
\text { B: } \\
\text { 70\%HA-30\% Coll I } \\
\text { 30\%HA-70\%Coll I } \\
\text { /Finceramica, Italy }\end{array}$ & 2011-2016 & $3.6 \pm 0.85$ & 24 & $\begin{array}{l}\text { Satisfactory mid-term follow-up results and } \\
\text { quicker return to sports. Low complication and } \\
\text { failure rates. }\end{array}$ \\
\hline Verhaegen et al., 2015 & $\begin{array}{l}\text { Systematic } \\
\text { review }\end{array}$ & 130 & $\begin{array}{l}\text { TruFit } \\
\text { Biphasic } \\
\text { C: PGA, PLGA, surfactant } \\
\text { B: Ca Sulfate } \\
\text { /Smith \& Nephew, United } \\
\text { States }\end{array}$ & 2010-1015 & N/A & 12 & $\begin{array}{l}\text { No evidence for TruFit being superior or equal } \\
\text { to other techniques. Longer follow ups result in } \\
\text { poorer outcomes. Subchondral integration is } \\
\text { inferior with bone cysts reported. Chondral } \\
\text { regenerate contains fibroblastic tissue. }\end{array}$ \\
\hline Kon et al., 2014 & Case report & 1 & $\begin{array}{l}\text { Agili-C } \\
\text { Biphasic } \\
\text { C: Modified aragonite + HA } \\
\text { B: Aragonite } \\
\text { /CartiHeal (2009) Ltd, Israel }\end{array}$ & 2015-2020 & 2 & 24 & $\begin{array}{l}\text { MRI: Good tissue integration. Regenerate } \\
\text { resembled hyaline cartilage. VAS, Lysholm. } \\
\text { Tegner, IKDC scores significantly improved with } \\
\text { excellent outcomes }\end{array}$ \\
\hline
\end{tabular}


the failure of bony ingrowth and fissured lesions in the surface of the chondral regenerate at 24 months. Few studies reporting histology also showed the presence of subchondral cysts and fibrous cartilage, but it should be noted these were biopsies performed in patients that required revision (Dhollander et al., 2012; Joshi et al., 2012). TruFit being a synthetic scaffold appears to have issues with biodegradability and integration and therefore needs to be further improved before further clinical application (Verhaegen et al., 2015).

A more recent developed synthetic osteochondral implant is Agili-C which has a chondral phase made up of modified aragonite with hyaluronic acid and a bone phase of calcium carbonate. Only one clinical case report is published with most results of the Agili-C implant being in pre-clinical studies. Pre-clinical studies have shown excellent cell recruitment and biocompatibility of the materials (Kon et al., 2014, 2015; Chubinskaya et al., 2019). Kon et al recently reported the use of a hemicondylar aragonite implant in a caprine model. At 12 months follow up they found the implant promoted good chondral and subchondral regeneration, excellent integration and no adverse effects (Gomoll, 2020; Kon et al., 2020). In the clinical case study, a 47-year-old male patient underwent an osteochondral repair with Agili- $\mathrm{C}$ and reported significant improvement in functional outcome scores. Radiographic studies at 24 months indicated hyaline cartilage regeneration over the entire defect and good bone integration. Sequential radiography suggested the entire implant degraded and was substituted for cartilage and bone by creeping substitution. Results of the Agili$\mathrm{C}$ implant are encouraging, and a randomized clinical trial has been underway. Hopefully, in the near future, these results will be available to better evaluate and make recommendation guidelines for the use of Agili-C Table 3. Summarizes the clinical studies using multiphasic scaffolds.

\section{REFERENCES}

Aigner, T., and Dudhia, J. (1997). Phenotypic modulation of chondrocytes as a potential therapeutic target in osteoarthritis: a hypothesis. Ann. Rheum. Dis. 56, 287-291. doi: 10.1136/ard.56.5.287

Ando, W., Tateishi, K., Hart, D. A., Katakai, D., Tanaka, Y., Nakata, K., et al. (2007). Cartilage repair using an in vitro generated scaffold-free tissue-engineered construct derived from porcine synovial mesenchymal stem cells. Biomaterials 28, 5462-5470. doi: 10.1016/j.biomaterials.2007.08.030

Angele, P., Schumann, D., Angele, M., Kinner, B., Englert, G., Hente, R., et al. (2004). Cyclic, mechanical compression enhances chondrogenesis of mesenchymal progenitor cells in tissue engineering scaffolds. Biorheology 41, 335-346.

Arvidson, K., Abdallah, B. M., Applegate, L. A., Baldini, N., Cenni, E., GomezBarrena, E., et al. (2011). Bone regeneration and stem cells. J. Cell. Mol. Med. 15, 718-746. doi: 10.1111/j.1582-4934.2010.01224.x

Ateshian, G. A., Warden, W. H., Kim, J. J., Grelsamer, R. P., and Mow, V. C. (1997). Finite deformation biphasic material properties of bovine articular cartilage from confined compression experiments. J. Biomech. 30, 1157-1164. doi: 10.1016/S0021-9290(97)85606-0

Baer, P. C., and Geiger, H. (2012). Adipose-derived mesenchymal stromal/stem cells: tissue localization, characterization, and heterogeneity. Stem Cells Int. 2012:812693. doi: 10.1155/2012/812693

Barrett, I., King, A. H., Riester, S., van Wijnen, A., Levy, B. A., Stuart, M. J., et al. (2016). Internal fixation of unstable osteochondritis dissecans in the

\section{FUTURE DIRECTION}

As several of the proposed strategies to treat OLs remains in experimental and pre-clinical phases, it is difficult to predict which will prove most useful in the clinical management of OLs. We see popular chondral substitutes being derived from polymers and ECMS while the subchondral materials frequently used are ceramics, bioglass, and metals. These materials seeded with stem cells, growth factors, different culture methods or bioactive ions show encouraging results with the most effective combination of these yet to be determined. Clinical recommendations for the use of osteochondral implants are awaited pending further welldesigned trials. The present literature reports encouraging results but in the interim osteochondral fragment fixation, OATs and OCA remain techniques with respectable outcomes so long as their specific indications and limitations are noted.

\section{AUTHOR CONTRIBUTIONS}

GJ wrote the first draft of the manuscript. KS and NN edited the manuscript. All authors contributed to manuscript revision, read and approved the submitted version.

\section{FUNDING}

This work was supported by a Health and Labor Sciences Research grant from the Ministry of Health, Labor, and Welfare of Japan (to NN); a grant from the New Energy and Industrial Technology Development Organization, Japan (to NN); and a Grant-in-Aid for Scientific Research, Japan Society for the Promotion of Science (to NN and KS).

skeletally mature knee with metal screws. Cartilage 7, 157-162. doi: 10.1177/ 1947603515622662

Barry, F., and Murphy, M. (2013). Mesenchymal stem cells in joint disease and repair. Nat. Rev. Rheumatol. 9, 584-594. doi: 10.1038/nrrheum.2013.109

Bentley, G., Biant, L. C., Carrington, R. W. J., Akmal, M., Goldberg, A., Williams, A. M., et al. (2003). A prospective, randomised comparison of autologous chondrocyte implantation versus mosaicplasty for osteochondral defects in the knee. J. Bone Jt. Surg. Ser. B 85, 223-230. doi: 10.1302/0301-620X.85B2.13543

Benya, P. D., and Shaffer, J. D. (1982). Dedifferentiated chondrocytes reexpress the differentiated collagen phenotype when cultured in agarose gels. Cell 30, 215-224. doi: 10.1016/0092-8674(82)90027-7

Berebichez-Fridman, R., Gómez-García, R., Granados-Montiel, J., BerebichezFastlicht, E., Olivos-Meza, A., Granados, J., et al. (2017). The holy grail of orthopedic surgery: mesenchymal stem cells - their current uses and potential applications. Stem Cells Int. 2017:2638305. doi: 10.1155/2017/2638305

Bhattarai, S. R., Bhattarai, N., Viswanathamurthi, P., Yi, H. K., Hwang, P. H., and Kim, H. Y. (2006). Hydrophilic nanofibrous structure of polylactide; fabrication and cell affinity. J. Biomed. Mater. Res. Part A 78, 247-257. doi: 10.1002/jbm.a. 30695

Buchtová, N., Réthoré, G., Boyer, C., Guicheux, J., Rambaud, F., Vallé, K., et al. (2013). Nanocomposite hydrogels for cartilage tissue engineering: Mesoporous silica nanofibers interlinked with siloxane derived polysaccharide. J. Mater. Sci. Mater. Med. 24, 1875-1884. doi: 10.1007/s10856-013-4951-0

Buckwalter, J. A., and Mankin, H. J. (1997). Instructional course lectures, the american academy of orthopaedic surgeons - articular cartilage. part i: tissue 
design and chondrocyte-matrix interactions*† . J Bone Jt. Surg. Am. 79, 600-611. doi: 10.2106/00004623-199704000-00021

Campbell, J. J., Lee, D. A., and Bader, D. L. (2006). Dynamic compressive strain influences chondrogenic gene expression in human mesenchymal stem cells. Biorheology 43, 455-470.

Chahla, J., Cinque, M. E., Piuzzi, N. S., Mannava, S., Geeslin, A. G., Murray, I. R., et al. (2017). A call for standardization in platelet-rich plasma preparation protocols and composition reporting. J. Bone Jt. Surg. 99, 1769-1779. doi: $10.2106 /$ jbjs. 16.01374

Chahla, J., Piuzzi, N. S., Mitchell, J. J., Dean, C. S., Pascual-Garrido, C., LaPrade, R. F., et al. (2016). Intra-articular cellular therapy for osteoarthritis and focal cartilage defects of the knee: a systematic review of the literature and study quality analysis. J. Bone Jt. Surg. Am. 98, 1511-1521. doi: 10.2106/JBJS.15.01495

Charalambous, C. P. (2014). Cell origin and differentiation in the repair of fullthickness defects of articular cartilage. Class. Pap. Orthop. 75, 377-379. doi: 10.1007/978-1-4471-5451-8_95

Chen, C. H., Kuo, C. Y., and Chen, J. P. (2018). Effect of cyclic dynamic compressive loading on chondrocytes and adipose-derived stem cells co-cultured in highly elastic cryogel scaffolds. Int. J. Mol. Sci. 19:370. doi: 10.3390/ijms19020370

Chen, J., Chen, H., Li, P., Diao, H., Zhu, S., Dong, L., et al. (2011). Simultaneous regeneration of articular cartilage and subchondral bone in vivo using MSCs induced by a spatially controlled gene delivery system in bilayered integrated scaffolds. Biomaterials 32, 4793-4805. doi: 10.1016/j.biomaterials.2011.03.041

Cheng, N. C., Estes, B. T., Awad, H. A., and Guilak, F. (2009). Chondrogenic differentiation of adipose-derived adult stem cells by a porous scaffold derived from native articular cartilage extracellular matrix. Tissue Eng. Part A 15, 231-241. doi: 10.1089/ten.tea.2008.0253

Chijimatsu, R., Ikeya, M., Yasui, Y., Ikeda, Y., Ebina, K., Moriguchi, Y., et al. (2017). Characterization of mesenchymal stem cell-like cells derived from human iPSCs via neural crest development and their application for osteochondral repair. Stem Cells Int. 2017:1960965. doi: 10.1155/2017/1960965

Chubinskaya, S., Di Matteo, B., Lovato, L., Iacono, F., Robinson, D., and Kon, E. (2019). Agili-C implant promotes the regenerative capacity of articular cartilage defects in an ex vivo model. Knee Surg. Sport Traumatol. Arthrosc. 27, 1953-1964. doi: 10.1007/s00167-018-5263-1

Conrad, J. M., and Stanitski, C. L. (2003). Osteochondritis dissecans: Wilson's sign revisited. Am. J. Sports Med. 31, 777-778. doi: 10.1177/03635465030310052301

Cuevas, P., Burgos, J., and Baird, A. (1988). Basic fibroblast growth factor (FGF) promotes cartilage repair in vivo. Biochem. Biophys. Res. Commun. 156, 611618. doi: 10.1016/s0006-291x(88)80887-8

D’Ambrosi, R., Valli, F., De Luca, P., Ursino, N., and Usuelli, F. (2019). MaioRegen osteochondral substitute for the treatment of knee defects: a systematic review of the literature. J. Clin. Med. 8:783. doi: 10.3390/jcm8060783

Darling, E. M., and Athanasiou, K. A. (2005). Rapid phenotypic changes in passaged articular chondrocyte subpopulations. J. Orthop. Res. 23, 425-432. doi: 10.1016/j.orthres.2004.08.008

de Mara, C. S., Sartori, A. R., Duarte, A. S., Andrade, A. L. L., Pedro, M. A. C., and Coimbra, I. B. (2011). Periosteum as a source of mesenchymal stem cells: The effects of TGF- $\beta 3$ on chondrogenesis. Clinics 66, 487-492. doi: 10.1590/S180759322011000300022

Deng, C., Chang, J., and Wu, C. (2019). Bioactive scaffolds for osteochondral regeneration. J. Orthop. Transl. 17, 15-25. doi: 10.1016/j.jot.2018.11.006

Deng, C., Yao, Q., Feng, C., Li, J., Wang, L., Cheng, G., et al. (2017). 3D printing of bilineage constructive biomaterials for bone and cartilage regeneration. $A d v$. Funct. Mater. 27:1703117. doi: 10.1002/adfm.201703117

Dhollander, A. A. M., Liekens, K., Almqvist, K. F., Verdonk, R., Lambrecht, S., Elewaut, D., et al. (2012). A pilot study of the use of an osteochondral scaffold plug for cartilage repair in the knee and how to deal with early clinical failures. Arthrosc. J. Arthrosc. Relat. Surg. 28, 225-233. doi: 10.1016/j.arthro.2011. 07.017

Duan, P., Pan, Z., Cao, L., He, Y., Wang, H., Qu, Z., et al. (2014). The effects of pore size in bilayered poly(lactide-co-glycolide) scaffolds on restoring osteochondral defects in rabbits. J. Biomed. Mater. Res. Part A 102, 180-192. doi: 10.1002/jbm. a.34683

Duncan, H., Jundt, J., Riddle, J. M., Pitchford, W., and Christopherson, T. (1987). The tibial subchondral plate. A scanning electron microscopic study. J. Bone Jt. Surg. Ser. A 69, 1212-1220. doi: 10.2106/00004623-198769080-00015
Ellman, M. B., An, H. S., Muddasani, P., and Im, H. J. (2008). Biological impact of the fibroblast growth factor family on articular cartilage and intervertebral disc homeostasis. Gene 420, 82-89. doi: 10.1016/j.gene.2008.04.019

Ellsworth, J. L., Berry, J., Bukowski, T., Claus, J., Feldhaus, A., Holderman, S., et al. (2002). Fibroblast growth factor-18 is a trophic factor for mature chondrocytes and their progenitors. Osteoarthr. Cartil. 10, 308-320. doi: 10.1053/joca.2002. 0514

Estes, B. T., and Guilak, F. (2011). Three-dimensional culture systems to induce chondrogenesis of adipose-derived stem cells. Methods Mol. Biol. 702, 201-217. doi: 10.1007/978-1-61737-960-4_15

Fortier, L. A., Barker, J. U., Strauss, E. J., McCarrel, T. M., and Cole, B. J. (2011). The role of growth factors in cartilage repair. Clin. Orthop. Relat. Res. 469, 2706-2715. doi: 10.1007/s11999-011-1857-3

Frank, E. H., and Grodzinsky, A. J. (1987). Cartilage electromechanics-I. Electrokinetic transduction and the effects of electrolyte $\mathrm{pH}$ and ionic strength. J. Biomech. 20, 615-627. doi: 10.1016/0021-9290(87)90282-X

Freyria, A. M., and Mallein-Gerin, F. (2012). Chondrocytes or adult stem cells for cartilage repair: the indisputable role of growth factors. Injury 43, 259-265. doi: 10.1016/j.injury.2011.05.035

Frisbie, D. D., Kawcak, C. E., Werpy, N. M., Park, R. D., and Mcllwraith, C. W. (2007). Clinical, biochemical, and histologic effects of intra-articular administration of autologous conditioned serum in horses with experimentally induced osteoarthritis. Am. J. Vet. Res. 68, 290-296. doi: 10.2460/ajvr.68.3.290

Gannon, F. H., and Sokoloff, L. (1999). Histomorphometry of the aging human patella: histologic criteria and controls. Osteoarthr. Cartil. 7, 173-181. doi: 10.1053/joca.1998.0206

Ghadially, F. N. (1981). Structure and Function of Articular Cartilage. Philadelphia, PA: Lippincott-Raven.

Gkiokas, A., Morassi, L. G., Kohl, S., Zampakides, C., Megremis, P., and Evangelopoulos, D. S. (2012). Bioabsorbable pins for treatment of osteochondral fractures of the knee after acute patella dislocation in children and young adolescents. Adv. Orthop. 2012:249687. doi: 10.1155/2012/249687

Gomoll, A. H. (2020). Aragonite-based implants for Osteochondral Defects Could coral make old goats run again? Arthrosc. J. Arthrosc. Relat. Surg. 36, 1895-1896. doi: 10.1016/j.arthro.2020.05.011

Gomoll, A. H., Madry, H., Knutsen, G., van Dijk, N., Seil, R., Brittberg, M., et al. (2010). The subchondral bone in articular cartilage repair: current problems in the surgical management. Knee Surg Sport Traumatol. Arthrosc. 18, 434-447. doi: 10.1007/s00167-010-1072-x

Gorbachova, T., Melenevsky, Y., Cohen, M., and Cerniglia, B. W. (2018). Osteochondral lesions of the knee: differentiating the most common entities at MRI. Radiographics 38, 1478-1495. doi: 10.1148/rg.2018180044

Gudas, R., Gudaite, A., Pocius, A., Gudiene, A., Ėekanauskas, E., Monastyreckiene, E., et al. (2012). Ten-year follow-up of a prospective, randomized clinical study of mosaic osteochondral autologous transplantation versus microfracture for the treatment of osteochondral defects in the knee joint of athletes. Am. J. Sports Med. 40, 2499-2508. doi: 10.1177/0363546512458763

Guermazi, A., Niu, J., Hayashi, D., Roemer, F. W., Englund, M., Neogi, T., et al. (2012). Prevalence of abnormalities in knees detected by MRI in adults without knee osteoarthritis: population based observational study (Framingham Osteoarthritis Study). BMJ 345:e5339. doi: 10.1136/bmj.e5339

Gunatillake, P. A., Adhikari, R., and Gadegaard, N. (2003). Biodegradable synthetic polymers for tissue engineering. Eur. Cells Mater. 5, 1-16. doi: 10.22203/eCM. v005a01

Haverkamp, D. J., Schiphof, D., Bierma-Zeinstra, S. M., Weinans, H., and Waarsing, J. H. (2011). Variation in joint shape of osteoarthritic knees. Arthritis Rheum. 63, 3401-3407. doi: 10.1002/art.30575

Hayes, W. C., and Bodine, A. J. (1978). Flow-independent viscoelastic properties of articular cartilage matrix. J. Biomech. 11, 407-419. doi: 10.1016/0021-9290(78) 90075- 1

Herring, M. J., Knudsen, M. L., and Macalena, J. A. (2019). Open reduction, bone grafting, and internal fixation of osteochondritis dissecans lesion of the knee. JBJS Essent. Surg. Tech. 9:e23. doi: 10.2106/jbjs.st.18.00035

Hirsch, G., and Boman, A. (1998). Osteochondral fractures of the knee in children and adolescents - Treatment with open reduction and osteosynthesis using biodegradable pins. Tech. Orthop. 13, 139-142. doi: 10.1097/00013611199806000-00007 
Hocking, A. M., and Gibran, N. S. (2010). Mesenchymal stem cells: paracrine signaling and differentiation during cutaneous wound repair. Exp. Cell Res. 316, 2213-2219. doi: 10.1016/j.yexcr.2010.05.009

Honner, R., and Thompson, R. C. (1971). The nutritional pathways of articular cartilage. An autoradiographic study in rabbits using 35 S injected intravenously. J. Bone Joint Surg. Am. 53, 742-748. doi: 10.2106/00004623-197153040-00013

Huang, C.-Y. C., Hagar, K. L., Frost, L. E., Sun, Y., and Cheung, H. S. (2004). Effects of cyclic compressive loading on chondrogenesis of rabbit bone-marrow derived mesenchymal stem cells. Stem Cells 22, 313-323. doi: 10.1634/stemcells. 22-3-313

Huang, L., Yi, L., Zhang, C., He, Y., Zhou, L., Liu, Y., et al. (2018). Synergistic effects of FGF-18 and TGF- $\beta 3$ on the chondrogenesis of human adipose-derived mesenchymal stem cells in the pellet culture. Stem Cells Int. doi: 10.1155/2018/ 7139485

Hubka, K. M., Dahlin, R. L., Meretoja, V. V., Kasper, F. K., and Mikos, A. G. (2014). Enhancing chondrogenic phenotype for cartilage tissue engineering: monoculture and coculture of articular chondrocytes and mesenchymal stem cells. Tissue Eng. Part B Rev. 20, 641-654. doi: 10.1089/ten.teb.2014.0034

Hunter, D. J., Buck, R., Vignon, E., Eckstein, F., Brandt, K., Mazzuca, S. A., et al. (2009). Relation of regional articular cartilage morphometry and meniscal position by MRI to joint space width in knee radiographs. Osteoarthr. Cartil. 17, 1170-1176. doi: 10.1016/j.joca.2009.04.001

Imhof, H., Sulzbacher, I., Grampp, S., Czerny, C., Youssefzadeh, S., and Kainberger, F. (2000). Subchondral bone and cartilage disease: a rediscovered functional unit. Invest. Radiol. 35, 581-588. doi: 10.1097/00004424-2000100000004

Jackson, W. M., Nesti, L. J., and Tuan, R. S. (2010). Potential therapeutic applications of muscle-derived mesenchymal stem and progenitor cells. Expert Opin. Biol. Ther. 10, 505-517. doi: 10.1517/14712591003610606

Jacob, G., Shetty, V., and Shetty, S. (2017). A study assessing intra-articular PRP vs PRP with HMW HA vs PRP with LMW HA in early knee osteoarthritis. J. Arthrosc. Jt. Surg. 4, 65-71. doi: 10.1016/j.jajs.2017.08.008

Jeuken, R. M., Vles, G. F., Jansen, E. J. P., Loeffen, D., and Emans, P. J. (2019). The modified hedgehog technique to repair pure chondral shear-off lesions in the pediatric knee. Cartilage. doi: 10.1177/1947603519855762 [Epub ahead of print].

Johnstone, B., Hering, T. M., Caplan, A. I., Goldberg, V. M., and Yoo, J. U. (1998). In vitro chondrogenesis of bone marrow-derived mesenchymal progenitor cells. Exp. Cell Res. 238, 265-272. doi: 10.1006/excr.1997.3858

Joshi, N., Reverte-Vinaixa, M., Díaz-Ferreiro, E. W., and Domínguez-Oronoz, R. (2012). Synthetic resorbable scaffolds for the treatment of isolated patellofemoral cartilage defects in young patients: magnetic resonance imaging and clinical evaluation. Am. J. Sports Med. 40, 1289-1295. doi: 10.1177/ 0363546512441585

Kanazawa, H., Fujimoto, Y., Teratani, T., Iwasaki, J., Kasahara, N., Negishi, K., et al. (2011). Bone marrow-derived mesenchymal stem cells ameliorate hepatic ischemia reperfusion injury in a rat model. PLoS One 6:e19195. doi: 10.1371/ journal.pone.0019195

Kandel, R. A., Gross, A. E., Ganel, A., McDermott, A. G., Langer, F., and Pritzker, K. P. (1985). Histopathology of failed osteoarticular shell allografts. Clin. Orthop. Relat. Res. 197, 103-110. doi: 10.1097/00003086-198507000-00012

Keeney, M., and Pandit, A. (2009). The osteochondral junction and its repair via bi-phasic tissue engineering scaffolds. Tissue Eng. Part B Rev. 15, 55-73. doi: $10.1089 /$ ten.teb.2008.0388

Ko, J. Y., Kim, K. I., Park, S., and Im, G. I. (2014). In vitro chondrogenesis and in vivo repair of osteochondral defect with human induced pluripotent stem cells. Biomaterials 35, 3571-3581. doi: 10.1016/j.biomaterials.2014. 01.009

Kon, E., Delcogliano, M., Filardo, G., Busacca, M., Di Martino, A., and Marcacci, M. (2011). Novel nano-composite multilayered biomaterial for osteochondral regeneration: a pilot clinical trial. Am. J. Sports Med. 39, 1180-1190. doi: 10. 1177/0363546510392711

Kon, E., Delcogliano, M., Filardo, G., Fini, M., Giavaresi, G., Francioli, S., et al. (2010). Orderly osteochondral regeneration in a sheep model using a novel nano-composite multilayered biomaterial. J. Orthop. Res. 28, 116-124. doi: 10.1002/jor.20958
Kon, E., Filardo, G., Robinson, D., Eisman, J. A., Levy, A., Zaslav, K., et al. (2014). Osteochondral regeneration using a novel aragonite-hyaluronate biphasic scaffold in a goat model. Knee Surg. Sport Traumatol. Arthrosc. 22, 1452-1464. doi: 10.1007/s00167-013-2467-2

Kon, E., Filardo, G., Shani, J., Altschuler, N., Levy, A., Zaslav, K., et al. (2015). Osteochondral regeneration with a novel aragonite-hyaluronate biphasic scaffold: up to 12-month follow-up study in a goat model. J. Orthop. Surg. Res. 10:81. doi: 10.1186/s13018-015-0211-y

Kon, E., Robinson, D., Shani, J., Alves, A., Di Matteo, B., Ashmore, K., et al. (2020). Reconstruction of large osteochondral defects using a hemicondylar aragonite-based implant in a caprine model. Arthrosc. J. Arthrosc. Relat. Surg. 36, 1884-1894. doi: 10.1016/j.arthro.2020.02.026

Krych, A. J., Pareek, A., King, A. H., Johnson, N. R., Stuart, M. J., and Williams, R. J. (2017). Return to sport after the surgical management of articular cartilage lesions in the knee: a meta-analysis. Knee Surg. Sport Traumatol. Arthrosc. 25, 3186-3196. doi: 10.1007/s00167-016-4262-3

Kundu, J., Pati, F., Hun Jeong, Y., and Cho, D. W. (2013). "Biomaterials for biofabrication of 3D tissue scaffolds," in Biofabrication: Micro- and NanoFabrication, Printing, Patterning and Assemblies, 23-46. doi: 10.1016/B978-14557-2852-7.00002-0

Langer, F., and Gross, A. E. (1974). Immunogenicity of allograft articular cartilage. J. Bone Jt. Surg. Ser. A 56, 297-304. doi: 10.2106/00004623-197456020-00007

Lee, E. S., Kwon, M. J., Lee, H., Na, K., and Kim, J. J. (2006). In vitro study of lysozyme in poly(lactide-co-glycolide) microspheres with sucrose acetate isobutyrate. Eur. J. Pharm. Sci. 29, 435-441. doi: 10.1016/j.ejps.2006.08.005

Lepage, S. I. M., Robson, N., Gilmore, H., Davis, O., Hooper, A., St John, S., et al. (2019). Beyond cartilage repair: the role of the osteochondral unit in joint health and disease. Tissue Eng. Part B Rev. 25, 114-125. doi: 10.1089/ten.teb.2018.0122

Levy, Y. D., Görtz, S., Pulido, P. A., McCauley, J. C., and Bugbee, W. D. (2013). Do fresh osteochondral allografts successfully treat femoral condyle lesions? Clin. Orthopaed. Relat. Res. 471, 231-237. doi: 10.1007/s11999-012-2556-4

Li, W. J., Mauck, R. L., Cooper, J. A., Yuan, X., and Tuan, R. S. (2007). Engineering controllable anisotropy in electrospun biodegradable nanofibrous scaffolds for musculoskeletal tissue engineering. J. Biomech. 40, 1686-1693. doi: 10.1016/j. jbiomech.2006.09.004

Liou, J. J., Rothrauff, B. B., Alexander, P. G., and Tuan, R. S. (2018). Effect of platelet-rich plasma on chondrogenic differentiation of adipose- and bone marrow-derived mesenchymal stem cells. Tissue Eng. Part A 24, 1432-1443. doi: 10.1089/ten.tea.2018.0065

Lo, B., and Parham, L. (2009). Ethical issues in stem cell research. Endocr. Rev. 30, 204-213. doi: 10.1210/er.2008-0031

Loeser, R. F., Goldring, S. R., Scanzello, C. R., and Goldring, M. B. (2012). Osteoarthritis: a disease of the joint as an organ. Arthritis Rheum. 64, 16971707. doi: 10.1002/art.34453

Loeser, R. F., Pacione, C. A., and Chubinskaya, S. (2003). The combination of insulin-like growth factor 1 and osteogenic protein 1 promotes increased survival of and matrix synthesis by normal and osteoarthritic human articular chondrocytes. Arthritis Rheum. 48, 2188-2196. doi: 10.1002/art.11209

Longley, R., Ferreira, A. M., and Gentile, P. (2018). Recent approaches to the manufacturing of biomimetic multi-phasic scaffolds for osteochondral regeneration. Int. J. Mol. Sci. 19:1755. doi: 10.3390/ijms19061755

Lopa, S., and Madry, H. (2014). Bioinspired scaffolds for osteochondral regeneration. Tissue Eng. Part A 20, 2052-2076. doi: 10.1089/ten.tea.2013.0356

Lv, Y. M., and Yu, Q. S. (2015). Repair of articular osteochondral defects of the knee joint using a composite lamellar scaffold. Bone Jt. Res. 4, 56-64. doi: 10.1302/2046-3758.44.2000310

Lynch, T. S., Patel, R. M., Benedick, A., Amin, N. H., Jones, M. H., and Miniaci, A. (2015). Systematic review of autogenous osteochondral transplant outcomes. Arthrosc. J. Arthrosc. Relat. Surg. 31, 746-754. doi: 10.1016/j.arthro.2014.11.018

Lyons, T. J., McClure, S. F., Stoddart, R. W., and McClure, J. (2006). The normal human chondro-osseous junctional region: evidence for contact of uncalcified cartilage with subchondral bone and marrow spaces. BMC Musculoskelet. Disord. 7:52. doi: 10.1186/1471-2474-7-52

Madry, H., van Dijk, C. N., and Mueller-Gerbl, M. (2010). The basic science of the subchondral bone. Knee Surg. Sport Traumatol. Arthrosc. 18, 419-433. doi: $10.1007 / \mathrm{s} 00167-010-1054-\mathrm{z}$ 
Mafi, R. (2011). Sources of adult mesenchymal stem cells applicable for musculoskeletal applications - a systematic review of the literature. Open Orthop. J. 5(Suppl. 2), 242-248. doi: 10.2174/1874325001105010242

Mano, J. F., and Reis, R. L. (2007). Osteochondral defects: present situation and tissue engineering approaches. J. Tissue Eng. Regen. Med. 1, 261-273. doi: 10. 1002/term.37

Maroudas, A., and Bullough, P. (1968). Permeability of articular cartilage. Nature 219, 1260-1261. doi: 10.1038/2191260a0

Marquass, B., Somerson, J. S., Hepp, P., Aigner, T., Schwan, S., Bader, A., et al. (2010). A novel MSC-seeded triphasic construct for the repair of osteochondral defects. J. Orthop. Res. 28, 1586-1599. doi: 10.1002/jor.21173

Martin, I., Miot, S., Barbero, A., Jakob, M., and Wendt, D. (2007). Osteochondral tissue engineering. J. Biomech. 40, 750-765. doi: 10.1016/j.jbiomech.2006. 03.008

Matsusue, Y., Yamamuro, T., and Hama, H. (1993). Arthroscopic multiple osteochondral transplantation to the chondral defect in the knee associated with anterior cruciate ligament disruption. Arthroscopy 9, 318-321. doi: 10.1016/ S0749-8063(05)80428-1

McCulloch, P. C., Kang, R. W., Sobhy, M. H., Hayden, J. K., and Cole, B. J. (2007). Prospective evaluation of prolonged fresh osteochondral allograft transplantation of the femoral condyle: minimum 2-year follow-up. Am. J. Sports Med. 35, 411-420. doi: 10.1177/0363546506295178

McMillan, S., Saini, S., Alyea, E., and Ford, E. (2017). Office-based needle arthroscopy: a standardized diagnostic approach to the knee. Arthrosc. Tech. 6, e1119-e1124. doi: 10.1016/j.eats.2017.03.031

Mente, P. L., and Lewis, J. L. (1994). Elastic modulus of calcified cartilage is an order of magnitude less than that of subchondral bone. J. Orthop. Res. 12, 637-647. doi: 10.1002/jor.1100120506

Miao, X., Tan, D. M., Li, J., Xiao, Y., and Crawford, R. (2008). Mechanical and biological properties of hydroxyapatite/tricalcium phosphate scaffolds coated with poly(lactic-co-glycolic acid). Acta Biomater. 4, 638-645. doi: 10.1016/j. actbio.2007.10.006

Millington, K. L., Shah, J. P., Dahm, D. L., Levy, B. A., and Stuart, M. J. (2010). Bioabsorbable fixation of unstable osteochondritis dissecans lesions. Am. J. Sports Med. 38, 2065-2070. doi: 10.1177/0363546510371369

Mishra, A., Tummala, P., King, A., Lee, B., Kraus, M., Tse, V., et al. (2009). Buffered platelet-rich plasma enhances mesenchymal stem cell proliferation and chondrogenic differentiation. Tissue Eng. Part C Methods 15, 431-435. doi: $10.1089 /$ ten.tec.2008.0534

Miyanishi, K., Trindade, M. C. D., Lindsey, D. P., Beaupré, G. S., Carter, D. R., Goodman, S. B., et al. (2006). Effects of hydrostatic pressure and transforming growth factor- $\beta 3$ on adult human mesenchymal stem cell chondrogenesis in vitro. Tissue Eng. 12, 1419-1428. doi: 10.1089/ten.2006.12.1419

Morille, M., Van-Thanh, T., Garric, X., Cayon, J., Coudane, J., Noël, D., et al. (2013). New PLGA-P188-PLGA matrix enhances TGF- $\beta 3$ release from pharmacologically active microcarriers and promotes chondrogenesis of mesenchymal stem cells. J. Control. Release 170, 99-110. doi: 10.1016/j.jconrel. 2013.04.017

Mouw, J. K., Connelly, J. T., Wilson, C. G., Michael, K. E., and Levenston, M. E. (2007). Dynamic compression regulates the expression and synthesis of chondrocyte-specific matrix molecules in bone marrow stromal cells. Stem Cells 25, 655-663. doi: 10.1634/stemcells.2006-0435

Mow, V. C., Holmes, M. H., and Michael Lai, W. (1984). Fluid transport and mechanical properties of articular cartilage: a review. J. Biomech. 17, 377-394. doi: 10.1016/0021-9290(84)90031-9

Mow, V. C., Kuei, S. C., Lai, W. M., and Armstrong, C. G. (1980). Biphasic creep and stress relaxation of articular cartilage in compression: theory and experiments. J. Biomech. Eng. 102, 73-84. doi: 10.1115/1.3138202

Nielsen, E. S., McCauley, J. C., Pulido, P. A., and Bugbee, W. D. (2017). Return to sport and recreational activity after osteochondral allograft transplantation in the knee. Am. J. Sports Med. 45, 1608-1614. doi: 10.1177/0363546517694857

Nooeaid, P., Salih, V., Beier, J. P., and Boccaccini, A. R. (2012). Osteochondral tissue engineering: scaffolds, stem cells and applications. J. Cell. Mol. Med. 16, 2247-2270. doi: 10.1111/j.1582-4934.2012.01571.x

Ochi, M., Uchio, Y., Tobita, M., and Kuriwaka, M. (2001). Current concepts in tissue engineering technique for repair of cartilage defect. Artif. Organs 25, 172-179. doi: 10.1046/j.1525-1594.2001.025003172.x
Oegema, T. R., Carpenter, R. J., Hofmeister, F., and Thompson, R. C. (1997). The interaction of the zone of calcified cartilage and subchondral bone in osteoarthritis. Microsc. Res. Tech. 37, 324-332. doi: 10.1002/(SICI)10970029(19970515)37:4<324::AID-JEMT7<3.0.CO;2-K

Orth, P., Meyer, H. L., Goebel, L., Eldracher, M., Ong, M. F., Cucchiarini, M., et al. (2013). Improved repair of chondral and osteochondral defects in the ovine trochlea compared with the medial condyle. J. Orthop. Res. 31, 1772-1779. doi: 10.1002/jor.22418

Pan, J., Zhou, X., Li, W., Novotny, J. E., Doty, S. B., and Wang, L. (2009). In situ measurement of transport between subchondral bone and articular cartilage. J. Orthop. Res. 27, 1347-1352. doi: 10.1002/jor.20883

Pareek, A., Reardon, P. J., Maak, T. G., Levy, B. A., Stuart, M. J., and Krych, A. J. (2016). Long-term outcomes after osteochondral autograft transfer: a systematic review at mean follow-up of 10.2 years. Arthrosc. J. Arthrosc. Relat. Surg. 32, 1174-1184. doi: 10.1016/j.arthro.2015.11.037

Pascual-Garrido, C., Friel, N. A., Kirk, S. S., McNickle, A. G., Bach, B. R., BushJoseph, C. A., et al. (2009). Midterm results of surgical treatment for adult osteochondritis dissecans of the knee. Am. J. Sports Med. 37(Suppl. 1), 125S130S. doi: $10.1177 / 0363546509350833$

Pelttari, K., Steck, E., and Richter, W. (2008). The use of mesenchymal stem cells for chondrogenesis. Injury 39(Suppl. 1), S58-S65. doi: 10.1016/j.injury.2008.01.038

Peña, J., Corrales, T., Izquierdo-Barba, I., Serrano, M. C., Portolés, M. T., Pagani, R., et al. (2006). Alkaline-treated poly( $\varepsilon$-caprolactone) films: degradation in the presence or absence of fibroblasts. J. Biomed. Mater. Res. Part A 76, 788-797. doi: $10.1002 / j b m . a .30547$

Pierdomenico, L., Bonsi, L., Calvitti, M., Rondelli, D., Arpinati, M., Chirumbolo, G., et al. (2005). Multipotent mesenchymal stem cells with immunosuppressive activity can be easily isolated from dental pulp. Transplantation $80,836-842$. doi: 10.1097/01.tp.0000173794.72151.88

Puetzer, J., Williams, J., Gillies, A., Bernacki, S., and Loboa, E. G. (2013). The effects of cyclic hydrostatic pressure on chondrogenesis and viability of human adipose-and bone marrow-derived mesenchymal stem cells in threedimensional agarose constructs. Tissue Eng. Part A 19, 299-306. doi: 10.1089/ ten.tea.2012.0015

Re'Em, T., Witte, F., Willbold, E., Ruvinov, E., and Cohen, S. (2012). Simultaneous regeneration of articular cartilage and subchondral bone induced by spatially presented TGF-beta and BMP-4 in a bilayer affinity binding system. Acta Biomater. 8, 3283-3293. doi: 10.1016/j.actbio.2012.05.014

Ren, J., Zhao, P., Ren, T., Gu, S., and Pan, K. (2008). Poly (D,L-lactide)/nanohydroxyapatite composite scaffolds for bone tissue engineering and biocompatibility evaluation. J. Mater. Sci. Mater. Med. 19, 1075-1082. doi: 10.1007/s10856-007-3181-8

Reyes, R., Delgado, A., Sánchez, E., Fernández, A., Hernández, A., and Evora, C. (2014). Repair of an osteochondral defect by sustained delivery of BMP-2 or TGF 1 from a bilayered alginate-PLGA scaffold. J. Tissue Eng. Regen. Med. 8, 521-533. doi: 10.1002/term.1549

Richter, D. L., Tanksley, J. A., and Miller, M. D. (2016). Osteochondral autograft transplantation: a review of the surgical technique and outcomes. Sports Med. Arthrosc. 24, 74-78. doi: 10.1097/JSA.0000000000000099

Ruiz, M., Cosenza, S., Maumus, M., Jorgensen, C., and Noël, D. (2016). Therapeutic application of mesenchymal stem cells in osteoarthritis. Exp. Opin. Biol. Ther. 16, 33-42. doi: 10.1517/14712598.2016.1093108

Rutgers, M., Saris, D. B. F., Dhert, W. J. A., and Creemers, L. B. (2010). Cytokine profile of autologous conditioned serum for treatment of osteoarthritis, in vitro effects on cartilage metabolism and intra-articular levels after injection. Arthritis Res. Ther. 12:R114. doi: 10.1186/ar3050

Sakaguchi, Y., Sekiya, I., Yagishita, K., and Muneta, T. (2005). Comparison of human stem cells derived from various mesenchymal tissues: Superiority of synovium as a cell source. Arthritis Rheum. 52, 2521-2529. doi: 10.1002/art. 21212

Salgado, A. J., Coutinho, O. P., and Reis, R. L. (2004). Bone tissue engineering: State of the art and future trends. Macromol. Biosci. 4, 743-765. doi: 10.1002/ mabi. 200400026

Samsudin, E. Z., and Kamarul, T. (2016). The comparison between the different generations of autologous chondrocyte implantation with other treatment modalities: a systematic review of clinical trials. Knee Surg. Sport Traumatol. Arthrosc. 4, 3912-3926. doi: 10.1007/s00167-015-3649-x 
Schek, R. M., Taboas, J. M., Segvich, S. J., Hollister, S. J., and Krebsbach, P. H. (2004). Engineered osteochondral grafts using biphasic composite solid freeform fabricated scaffolds. Tissue Eng. 10, 1376-1385. doi: 10.1089/ten.2004.10. 1376

Schmidt, M. B., Chen, E. H., and Lynch, S. E. (2006). A review of the effects of insulin-like growth factor and platelet derived growth factor on in vivo cartilage healing and repair. Osteoarthr. Cartil. 14, 403-412. doi: 10.1016/j.joca.2005. 10.011

Schnabel, M., Marlovits, S., Eckhoff, G., Fichtel, I., Gotzen, L., Vécsei, V., et al. (2002). Dedifferentiation-associated changes in morphology and gene expression in primary human articular chondrocytes in cell culture. Osteoarthr. Cartil. 10, 62-70. doi: 10.1053/joca.2001.0482

Sherman, S. L., Garrity, J., Bauer, K., Cook, J., Stannard, J., and Bugbee, W. (2014). Fresh osteochondral allograft transplantation for the knee: current concepts. J. Am. Acad. Orthop. Surg. 22, 121-133. doi: 10.5435/JAAOS-22-02-121

Shimomura, K., Moriguchi, Y., Ando, W., Nansai, R., Fujie, H., Hart, D. A., et al. (2014a). Osteochondral repair using a scaffold-free tissue-engineered construct derived from synovial mesenchymal stem cells and a hydroxyapatite-based artificial bone. Tissue Eng. Part A 20, 2291-2304. doi: 10.1089/ten.tea.2013. 0414

Shimomura, K., Moriguchi, Y., Murawski, C. D., Yoshikawa, H., and Nakamura, N. (2014b). Osteochondral tissue engineering with biphasic scaffold: current strategies and techniques. Tissue Eng. Part B Rev. 20, 468-476. doi: 10.1089/ ten.teb.2013.0543

Shimomura, K., Moriguchi, Y., Nansai, R., Fujie, H., Ando, W., Horibe, S., et al. (2017). Comparison of 2 different formulations of artificial bone for a hybrid implant with a tissue-engineered construct derived from synovial mesenchymal stem cells. Am. J. Sports Med. 45, 666-675. doi: 10.1177/0363546516668835

Sofat, N., Ejindu, V., and Kiely, P. (2011). What makes osteoarthritis painful? The evidence for local and central pain processing. Rheumatology 50, 2157-2165. doi: 10.1093/rheumatology/ker283

Sohni, A., and Verfaillie, C. M. (2013). Mesenchymal stem cells migration homing and tracking. Stem Cells Int. 2013:130763. doi: 10.1155/2013/130763

Solheim, E., Hegna, J., Strand, T., Harlem, T., and Inderhaug, E. (2018). Randomized study of long-term (15-17 years) outcome after microfracture versus mosaicplasty in knee articular cartilage defects. Am. J. Sports Med. 46, 826-831. doi: 10.1177/0363546517745281

Sonny Bal, B., Rahaman, M. N., Jayabalan, P., Kuroki, K., Cockrell, M. K., Yao, J. Q., et al. (2010). In vivo outcomes of tissue-engineered osteochondral grafts. J. Biomed. Mater. Res. Part B Appl. Biomater. 93, 164-174. doi: 10.1002/jbm.b. 31571

Sophia Fox, A. J., Bedi, A., and Rodeo, S. A. (2009). The basic science of articular cartilage: structure, composition, and function. Sports Health 1, 461-468. doi: $10.1177 / 1941738109350438$

Stevenson, S., Shaffer, J. W., and Goldberg, V. M. (1996). The humoral response to vascular and nonvascular allografts of bone. Clin. Orthop. Relat.Res. 323, 86-95. doi: 10.1097/00003086-199605000-00011

Stewart, A. A., Byron, C. R., Pondenis, H., and Stewart, M. C. (2007). Effect of fibroblast growth factor-2 on equine mesenchymal stem cell monolayer expansion and chondrogenesis. Am. J. Vet. Res. 68, 941-945. doi: 10.2460/ajvr. 68.9 .941

Stewart, H. L., and Kawcak, C. E. (2018). The importance of subchondral bone in the pathophysiology of osteoarthritis. Front. Vet. Sci. 5:178. doi: 10.3389/fvets. 2018.00178

Stewart, M. C., Saunders, K. M., Burton-Wurster, N., and MacLeod, J. N. (2000). Phenotypic stability of articular chondrocytes in vitro: the effects of culture models, bone morphogenetic protein 2, and serum supplementation. J. Bone Miner. Res. 15, 166-174. doi: 10.1359/jbmr.2000.15.1.166

Sundelacruz, S., and Kaplan, D. L. (2009). Stem cell- and scaffold-based tissue engineering approaches to osteochondral regenerative medicine. Semin. Cell Dev. Biol. 20, 646-655. doi: 10.1016/j.semcdb.2009.03.017

Sutherland, A. J., Converse, G. L., Hopkins, R. A., and Detamore, M. S. (2015). The bioactivity of cartilage extracellular matrix in articular cartilage regeneration. Adv. Healthc. Mater. 4, 29-39. doi: 10.1002/adhm.201400165

Takahashi, K., and Yamanaka, S. (2006). Induction of pluripotent stem cells from mouse embryonic and adult fibroblast cultures by defined factors. Cell 126, 663-676. doi: 10.1016/j.cell.2006.07.024
Tamai, N., Myoui, A., Hirao, M., Kaito, T., Ochi, T., Tanaka, J., et al. (2005). A new biotechnology for articular cartilage repair: Subchondral implantation of a composite of interconnected porous hydroxyapatite, synthetic polymer (PLAPEG), and bone morphogenetic protein-2 (rhBMP-2). Osteoarthr. Cartil. 13, 405-417. doi: 10.1016/j.joca.2004.12.014

Temenoff, J. S., and Mikos, A. G. (2000). Review: tissue engineering for regeneration of articular cartilage. Biomaterials 21, 431-440. doi: 10.1016/ S0142-9612(99)00213-6

Thomson, N. L. (1987). Osteochondritis dissecans and osteochondral fragments managed by Herbert compression screw fixation. Clin. Orthop. Relat. Res. 224, 71-78. doi: 10.1097/00003086-198711000-00010

Thorvaldsson, A., Stenhamre, H., Gatenholm, P., and Walkenström, P. (2008). Electrospinning of highly porous scaffolds for cartilage regeneration. Biomacromolecules 9, 1044-1049. doi: 10.1021/bm701225a

Tsumaki, N., Okada, M., and Yamashita, A. (2015). iPS cell technologies and cartilage regeneration. Bone 70, 48-54. doi: 10.1016/j.bone.2014. 07.011

Tuan, R. S., Chen, A. F., and Klatt, B. A. (2013). Cartilage regeneration. J. Am. Acad. Orthop. Surg. 21, 303-311. doi: 10.5435/JAAOS-21-05-303

Ulstein, S., Årøen, A., Røtterud, J. H., Løken, S., Engebretsen, L., and Heir, S. (2014). Microfracture technique versus osteochondral autologous transplantation mosaicplasty in patients with articular chondral lesions of the knee: a prospective randomized trial with long-term follow-up. Knee Surg. Sport Traumatol. Arthrosc. 22, 1207-1215. doi: 10.1007/s00167-0142843-6

Vats, A., Bielby, R. C., Tolley, N., Dickinson, S. C., Boccaccini, A. R., Hollander, A. P., et al. (2006). Chondrogenic differentiation of human embryonic stem cells: the effect of the micro-environment. Tissue Eng. 12, 1687-1697. doi: 10.1089/ten.2006.12.1687

Verhaegen, J., Clockaerts, S., Van Osch, G. J. V. M., Somville, J., Verdonk, P., and Mertens, P. (2015). TruFit plug for repair of osteochondral defects-where is the evidence? Systematic review of literature. Cartilage 6, 12-19. doi: 10.1177/ 1947603514548890

Villanueva, I., Weigel, C. A., and Bryant, S. J. (2009). Cell-matrix interactions and dynamic mechanical loading influence chondrocyte gene expression and bioactivity in PEG-RGD hydrogels. Acta Biomater. 5, 2832-2846. doi: 10.1016/ j.actbio.2009.05.039

Vogel, L. A., Fitzsimmons, K. P., and Lee Pace, J. (2020). Osteochondral fracture fixation with fragment preserving suture technique. Arthrosc. Tech. 9, e761e767. doi: 10.1016/j.eats.2020.02.018

Waldman, S. D., Couto, D. C., Grynpas, M. D., Pilliar, R. M., and Kandel, R. A. (2007). Multi-axial mechanical stimulation of tissue engineered cartilage: review. Eur. Cells Mater. 13, 66-73; discussion 73-4. doi: 10.22203/ecm. v013a07

Wei, F. Y., Lee, J. K., Wei, L., Qu, F., and Zhang, J. Z. (2017). Correlation of insulinlike growth factor 1 and osteoarthritic cartilage degradation: a spontaneous osteoarthritis in guinea-pig. Eur. Rev. Med. Pharmacol. Sci. 21, 4493-4500.

Williams, R. J., Ranawat, A. S., Potter, H. G., Carter, T., and Warren, R. F. (2007). Fresh stored allografts for the treatment of osteochondral defects of the knee. J. Bone Jt. Surg. Ser. A 89, 718-726. doi: 10.2106/JBJS.F.00625

Woo, S. L.-Y., Mow, V. C., Lai, W. M., Skalak, R., and Chien, S. (1987). "Biomechanical properties of articular cartilage," in Handbook of Bioengineering, eds R. Skalak and S. Chien (New York, NY: McGraw-Hill Book Co), 4.1-4.44

Woodfield, T. B. F., Van Blitterswijk, C. A., De Wijn, J., Sims, T. J., Hollander, A. P., and Riesle, J. (2005). Polymer scaffolds fabricated with pore-size gradients as a model for studying the zonal organization within tissue-engineered cartilage constructs. Tissue Eng. 11, 1297-1311. doi: 10.1089/ten.2005.11.1297

Xue, D., Zheng, Q., Zong, C., Li, Q., Li, H., Qian, S., et al. (2010). Osteochondral repair using porous poly(lactide-co-glycolide)/ nano-hydroxyapatite hybrid scaffolds with undifferentiated mesenchymal stem cells in a rat model. J. Biomed. Mater. Res. Part A 94, 259-270. doi: 10.1002/jbm.a.32691

Yang, K., Zhou, C., Fan, H., Fan, Y., Jiang, Q., Song, P., et al. (2018). Bio-functional design, application and trends in metallic biomaterials. Int. J. Mol. Sci. 19:24. doi: $10.3390 /$ ijms 19010024

Yang, P. J., and Temenoff, J. S. (2009). Engineering orthopedic tissue interfaces. Tissue Eng. Part B Rev. 15, 127-141. doi: 10.1089/ten.teb.2008.0371 
Yu, J., Vodyanik, M. A., Smuga-Otto, K., Antosiewicz-Bourget, J., Frane, J. L., Tian, S., et al. (2007). Induced pluripotent stem cell lines derived from human somatic cells. Science 318, 1917-1920. doi: 10.1126/science.1151526

Zhang, L., Su, P., Xu, C., Yang, J., Yu, W., and Huang, D. (2010). Chondrogenic differentiation of human mesenchymal stem cells: a comparison between micromass and pellet culture systems. Biotechnol. Lett. 32, 1339-1346. doi: 10.1007/s10529-010-0293-x

Zhang, S., Hu, B., Liu, W., Wang, P., Lv, X., Chen, S., et al. (2020). Articular cartilage regeneration: The role of endogenous mesenchymal stem/progenitor cell recruitment and migration. Semin. Arthritis Rheum. 50, 198-208. doi: 10. 1016/j.semarthrit.2019.11.001

Zhang, W., Chen, J., Tao, J., Hu, C., Chen, L., Zhao, H., et al. (2013). The promotion of osteochondral repair by combined intra-articular injection of parathyroid hormone-related protein and implantation of a bi-layer collagen-silk scaffold. Biomaterials 34, 6046-6057. doi: 10.1016/j.biomaterials.2013.04.055

Zhou, Q., Li, B., Zhao, J., Pan, W., Xu, J., and Chen, S. (2016). IGF-I induces adipose derived mesenchymal cell chondrogenic differentiation in vitro and enhances chondrogenesis in vivo. Vitr. Cell. Dev. Biol. Anim. 52, 356-364. doi: 10.1007/s11626-015-9969-9

Zhou, Y., Chyu, J., and Zumwalt, M. (2018). Recent progress of fabrication of cell scaffold by electrospinning technique for articular cartilage tissue engineering. Int. J. Biomater. 2018, doi: 10.1155/2018/195 3636

Conflict of Interest: The authors declare that the research was conducted in the absence of any commercial or financial relationships that could be construed as a potential conflict of interest.

Copyright (c) 2020 Jacob, Shimomura and Nakamura. This is an open-access article distributed under the terms of the Creative Commons Attribution License (CC BY).

The use, distribution or reproduction in other forums is permitted, provided the original author(s) and the copyright owner(s) are credited and that the original publication in this journal is cited, in accordance with accepted academic practice. No use, distribution or reproduction is permitted which does not comply with these terms. 